九州大学学術情報リポジトリ

Kyushu University Institutional Repository

Supplements to the Subgenus Simandrena of the Genus Andrena of China (Hymenoptera, Andrenidae)

$\mathrm{Xu}$, Huan- $\mathrm{i}$

Tadauchi, Osamu

https://doi.org/10.5109/2654

出版情報: ESAKIA. 41，pp. 155-160，2001-03-31. Entomological Laboratory，Faculty of Agriculture, Kyushu University

バージョン：

権利関係 : 


\title{
Supplements to the Subgenus Simandrena of the Genus Andrena of China (Hymenoptera, Andrenidae) 1), 2),3)
}

\author{
Huan-li XU ${ }^{4)}$ and Osamu TADAUCHI \\ Entomological laboratory, Faculty of Agriculture, \\ Kyushu University, Fukuoka, 812-8581 Japan
}

\begin{abstract}
A new species, Andrena (Simandrena) metuoensis is described from Tibet, southwest China. The male of $A$. (Simandrena) tiansana Tadauchi et $\mathrm{Xu}$ is described for the first time and $A$. (Simandrena) nippon Tadauchi et Hirashima is newly recorded from China.

Key words: taxonomy, Hymenoptera, Andrenidae, Andrena, Simandrena, China, new species.
\end{abstract}

Tadauchi and Xu (1995) gave a revision of the subgenus Simandrena of the genus Andrena of eastern Asia. Xu and Tadauchi (1998) placed Andrena subproxima Strand into this subgenus. In this paper, we add a new species of this subgenus from China, and describe the male of $A$. (Simandrena) tiansana Tadauchi et Xu and record $A$. (Simandrena) nippon Tadauchi et Hirashima from China for the first time. Eight species of the genus Simandrena are occurring in China at present. The holotype will be preserved in the Institute of Zoology, Academia Sinica, Beijing.

\section{Andrena (Simandrena) metuoensis n. sp.}

(Fig. 1: A-D)

Female. BL 9.0-9.5 mm, WL 7.5-8.7 mm (n=2).

Color: Flagellum ferruginous beneath except basal portion; mandible reddened apically; wing membranes hyaline, veins and pterostigma black; tibial spurs yellowish white; metasomal terga 1-2 and basal margin of terga with red maculae, posterior margins of terga red to dark red.

Pubescence: Hairs on head sparse, whitish to brown; those on clypeus 200-300 $\mu$,

1) Contribution from the Entomological Laboratory, Faculty of Agriculture, Kyushu University, Fukuoka (Ser. 5, No. 62).

2) This work was supported by a Grant-in-Aid for Scientific Research of an International Scientific Research Program from the Ministry of Education, Science, Sports and Culture, Japan (No. 07041144) (Head Investigator: O. Tadauchi).

3) Results from the China-Japan Co-operative Study on "Studies on Systematics, Evolution and Biogeography of Asian Andrena (Hym., Apoidea, Andrenidae)" No. 11.

4) Present address: Department of Vegetables and Flower Research, National Agricultural Research Center for Kyushu Okinawa Region, 1823-1 Miimachi, Kurume, Fukuoka, 839-8503 Japan. 
whitish, broadly naked medially; those on face above antennal fossae brown; those on vertex $400-500 \mu$, brown; those on genal area white; facial fovea brown. Hairs on mesoscutum $200-500 \mu$, sparse, dull white anteriorly, brown medially; those on scutellum naked broadly; those on mesepisternum $700 \mu$, whitish; propodeal corbicula completely developed, without internal hairs; trochanteral floccus perfect, white; femoral floccus dense; tibial scopal hairs rather short, simple, black. Hairs on metasomal terga rather short; those on terga 1-2 whitish; those on terga 3-4 black; terga 2-4 with complete white hair bands; caudal fimbria brown; sterna 2-5 with incomplete whitish subapical fimbriae.

Structure: Head: HL/HW = 0.80. HW: MsW: $\mathrm{MtW}=3.0: 3.0: 3.2$. Vertex short, shagreened. OOD: POD: $O C D=0.5: 0.3: 0.15$. FL1 shorter than FL2+3, FL2 = FL3 which are longer than broad, following segments longer than broad. Eyes with inner margins subparalleled. Facial fovea broad, extending to below a line at lower margin of antennal fossae, FVL $=1.2 \mathrm{~mm}, \mathrm{FVW}=0.4 \mathrm{~mm}$. Supraclypeal area densely tessellate with weak rugulae. Face above antennal fossae with fine longitudinal rugulae and obscure interrugal PP. Facial quadrangle as broad as long (about 2.1:2.1). Clypeus well convex, surface weakly tessellate except basal portion and lateral margins, feebly shiny with $\mathrm{PP} \varnothing 40 \mu$, IS $=0.5-1$ medially, smaller PP $\varnothing 20 \mu$, IS $=1-1.5$ laterally, with median indistinct impunctate line, $\mathrm{CPL}=1.0 \mathrm{~mm}$. Process of labrum moderate, trapezoidal, weakly emarginate apically. Labrum apical to process convex, median with weak cristae. Lower paraocular area weakly tessellate, shiny with minute $\mathrm{PP} \emptyset 20 \mu, \mathrm{IS}=0.5-1.5$. Malar space nearly linear. Genal area as broad as eye, $\mathrm{GW}: \mathrm{EW}=0.7: 0.7$, surface finely tessellate, PP obscured. Mesosoma: Pronotum densely tessellate. Mesoscutum strongly shagreened, surface opaque, occasionally feebly shiny posteriorly with minute PP, IS =

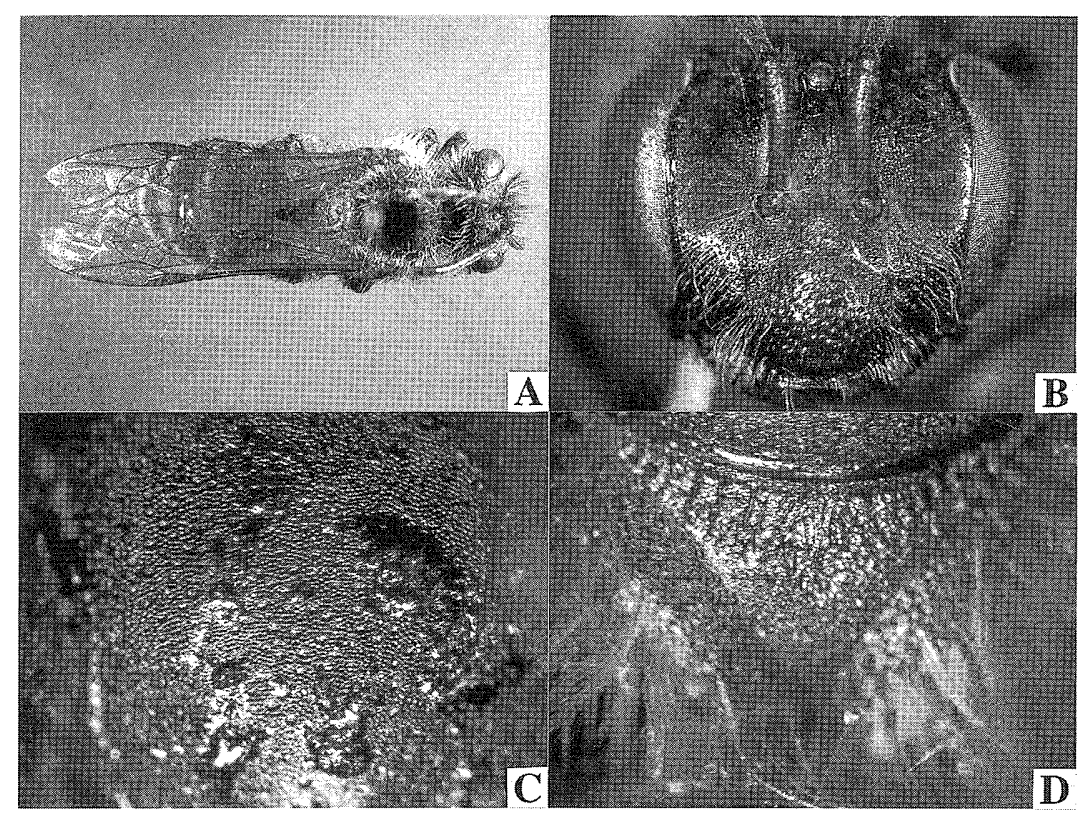

Fig. 1: A - D. Andrena (Simandrena) metuoensis sp. n., female. A: whole body; B: head in frontal view; C: mesoscutum; D: propodeum. 
1-2. Scutellum smooth and shiny to weakly tessellate, broadly impunctate medially. Propodeal enclosure densely tessellate, with sparse basal rugulae; dorsal face of propodeum densely tessellate with weak PP. Mesepisternum densely tessellate with scattered minute PP. Hind tibiae cuneate, middle basitarsi as broad as hind ones. Vein 1st $m-c u$ meeting second submarginal cell at middle of cell. Metasoma: Metasomal terga densely tessellate, impunctate; posterior depressions of terga not well indicated; pygidial plate V-shaped, with internal raised triangular area. Sterna 2-5 finely tessellate with fine PP, IS $=1-1.5$.

Male. Unknown.

Type material: Holotype female, Bangxin, 1,300 m, Metuo County, Xizang Autn. Region, China, 27. xi. 1982 (Y-h. Han). Paratype: 1 female, southwest Yunnan Province, China, vi. 1960 (Z-s. Zhang).

Remarks: This species is characteristic by having the metasomal terga 1-3 reddened as in A. transitoria Morawitz, But it is easily separated by the hairs on thorax normal, the scutellum shiny and broadly impunctate, the tibial scopa short and the metasomal terga impunctate. According to data, it may have two generations a year.

Distribution: China (Xizang, Yunnan Prov.).

Floral association: Not available.

\section{Andrena (Simandrena) tiansana Tadauchi et Xu}

(Fig. 2: A - E, Fig. 3: A - E)

Andrena (Simandrena) tiansana Tadauchi et Xu, 1995, Esakia, (35): 208-210 [female, China].

Male (new to science): BL 8.5-9.5 mm, WL 7.5-7.7 mm $(\mathrm{n}=2)$.

Color: Flagellum brown beneath; mandible with apical half reddened; wing membranes hyaline, veins yellow, pterostigma reddish brown; tibial spurs yellow; posterior margins of metasomal terga yellowish brown.

Pubescence: Hairs on head dense, white to pale yellow; those on clypeus about $500 \mu$, whitish; those on antennal area dull white; those on vertex $500-700 \mu$, pale yellow; those on genal area white; those on dorsum of thorax 500-700 $\mu$, dense, yellow; those on propodeum and mesepisternum whitish; legs with short white hairs. Hairs on metasomal terga sparse, white; those on tergum 1 long; those on terga 2-4 short, terga 2-4 with dense white hair bands, interrupted on tergum 2; terga 5-6 with long white hairs; sterna 2 5 with short, sparse white subapical fimbriae.

Structure: Head: HL/HW = 0.75. HW: MsW: $\mathrm{MtW}=3.0: 2.6: 2.8$. Vertex short, shagreened. OOD: POD: $\mathrm{OCD}=0.65: 0.4: 0.2$. FL1 < FL2, following segments distinctly longer than broad. Eyes with inner margins converging toward mandibles. Supraclypeal area weakly rugulose. Face above antennal fossae with dense longitudinal rugulae. Facial quadrangle as long as broad (about 1.9: 1.9). Clypeus weakly convex, surface crowdedly punctate with close PP $\emptyset 15 \mu$, IS $<0.5$, without median impunctate line, tessellate, $\mathrm{CPL}=0.9 \mathrm{~mm}$. Process of labrum small, subtrapezoidal, emarginate apically, surface smooth and shiny. Labrum apical to process without cristae. Mandibles decussate. Lower paraocular area weakly tessellate with minute PP, IS $=1$. Malar space nearly linear. Genal area narrower than eye, $\mathrm{GW}$ : $\mathrm{EW}=0.7: 0.8$, surface depressed, 
shagreened with weak rugulae. Mesosoma: Pronotum with surface reticularly shagreened, with weak PP anteriorly. Mesoscutum densely tessellate with minute PP, IS= 1-2 medially. Scutellum densely tessellate posteriorly, weakly tessellate anteriorly with minute PP, IS = 0.5-1, weakly shiny. Propodeal enclosure large, not well defined, densely tessellate with plicate rugulae basally; dorsal face of propodeum roughened by coarse punctation. Mesepisternum strongly tessellate, shagreened. Vein 1st $m$ - $c u$ meeting second submarginal cell at middle of cell. Metasoma: Metasomal tergum 1 with scattered microscopic PP apically; tergum 2 with weak minute PP, IS $=1-2$; terga 3-5 with same $\mathrm{PP}, \mathrm{IS}=1$; posterior depressions of terga well indicated. Sterna 2-5 finely tessellate with weak PP; sternum 6 emarginate, not reflected.

Specimens examined: Mt. Tianshan north slope, 1,600 m, Wuku Road, Xinjiang Uygur Autn. Region, China: 1 male, 10. vii. 1960 (F-c. Zhang); 1 male, 11. vi. 1960 (Sy. Wang).

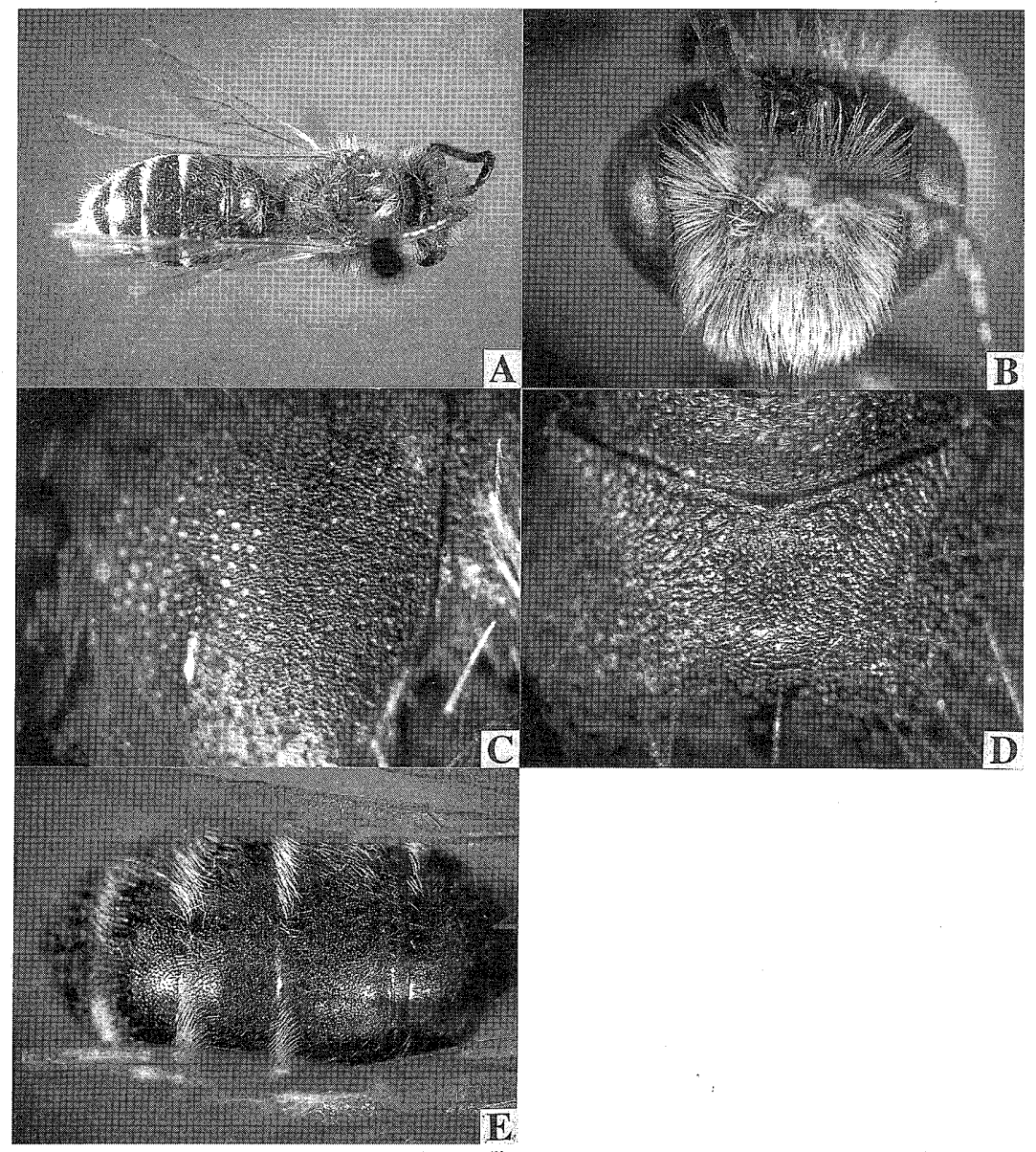

Fig. 2: A - E. Andrena (Simandrena) tiansana male. A: whole body; B: head in frontal view; C: mesoscutum; D: propodeum; E: metasomal terga. 

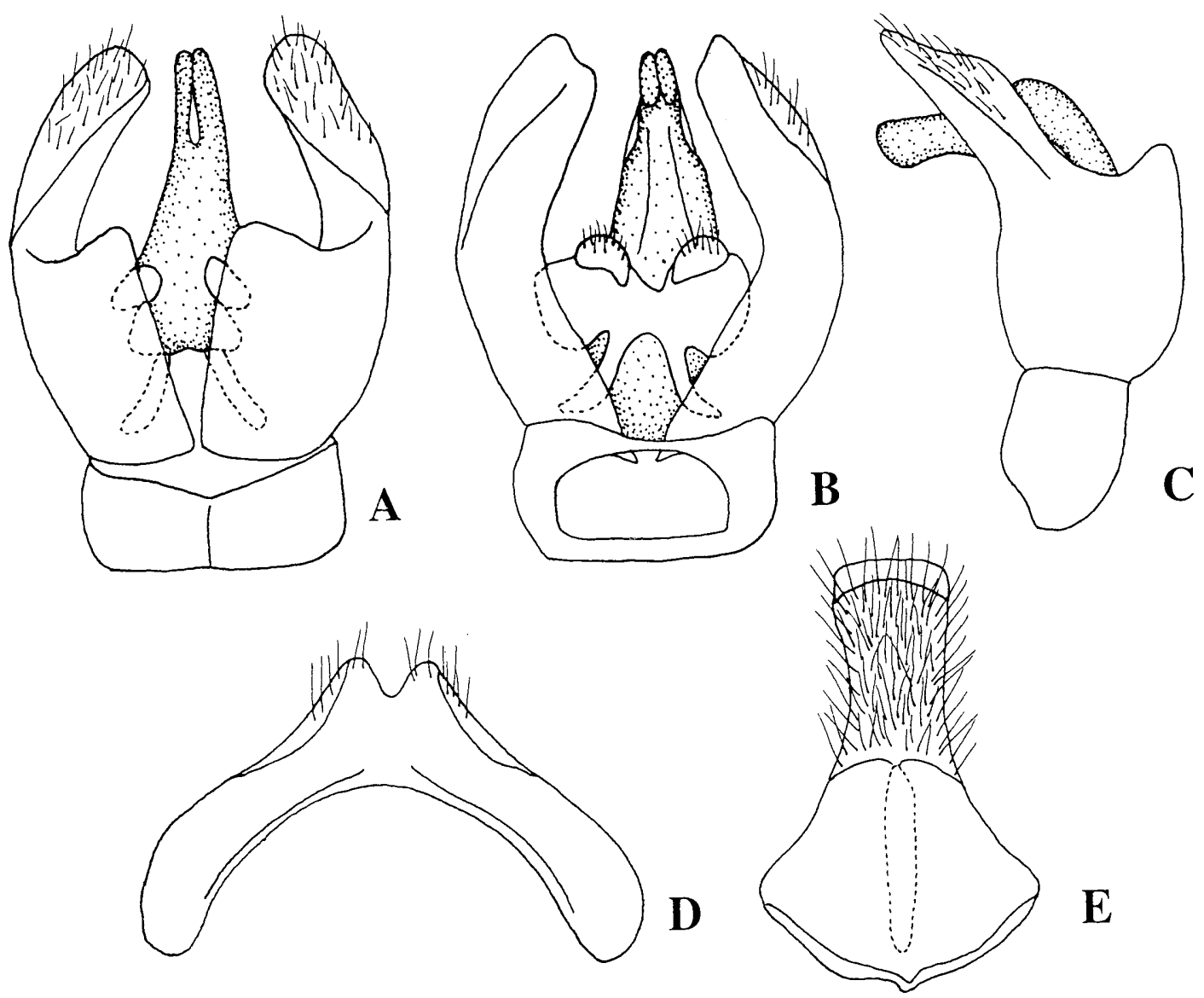

E

Fig. 3: A - E. Andrena (Simandrena) tiansana, male. Genital capsule and subgenital sterna. A: dorsal view of genital capsule; B: ventral view of the same; C: lateral view of the same; D: metasomal sternum 7; E: metasomal sternum 8.

Remarks: The male of this species is similar to A. kerriae Hirashima by having the clypeus with dense white hairs. But it is recognized by the 1st flagellar segment shorter than the second, the metasomal terga with very weak punctures and the propodeal enclosure less rugosed.

Distribution: China (Xinjiang Uygur Autn. Region).

Floral association: Not available.

\section{Andrena (Simandrena) nippon Tadauchi et Hirashima}

Andrena (Simandrena) kerriae: Hirashima. 1965, J. Fac. Agr., Kyushu Univ., 13: 499, in part [description] . 
Andrena (Simandrena) nippon Tadauchi et Hirashima, 1983, Esakia, (20): 89 [female \& male; Japan]; Tadauchi \& Xu, 1995, Esakia, (35): 215; Osytshnjuk, 1995, Key Insects Russian Far East, Vol. IV, Part 1, 508, 524 [female \& male, in key].

Specimens examined: Holotype female (Kyushu Univ., no. 2424): Hatahoko, Mt. Norikura, Gifu Pref., Japan, 8. v. 1976 (O. Tadauchi). Other material: China: Heilongjiang Province: 1 female, Jingpo Lake, Mudanjiang, 24. v. 1993 (O. Tadauchi).

Distribution: China (new record: Heilongjiang Prov.); Russia (Far East area); Japan (northern and central Honshu).

Floral associations (Japan): Brassica napus, Capsella bursa-pastoris, Taraxacum albidum.

\section{Acknowledgments}

We are grateful to Prof. Yan-ru Wu of Institute of Zoology, Academia Sinica, Beijing and Prof. Emeritus Y. Hirashima and Prof. J. Yukawa of Kyushu University, Fukuoka for their various help.

\section{References}

Tadauchi, O. \& H-1. Xu, 1995. A revision of the subgenus Simandrena of the genus Andrena from eastern Asia with a key to palaearctic species (Hymenoptera, Andrenidae). Easia, (35): 201-222.

Xu, H-l. \& O. Tadauchi, 1998. Subgeneric positions and redescriptions of Strand's Chinese Andrena preserved in the German Entomological Institute (D.E.I., Eberswalde) (Hymenoptera, Andrenidae). Esakia, (38): 89-103. 